\title{
STIGMATIZATION OF ISLAMIC SCHOOL: Pesantrens, Radicalism and Terrorism In Bima
}

\author{
Abdul Malik \\ State Islamic University (UIN) Mataram \\ Email: nakamalik@gmail.com
}

\begin{abstract}
This article aims to shed light on the stigmatization of two pesantrens in Bima as the base camp of radical and terrorist groups. The negative stigma attached to the pesantren has come to the fore due to the alleged affiliation of the school superintendents to several national terrorist groups. Such a stigmatization has promoted the belief that pesantren as an educational institution is increasingly becoming a home base that is lucrative to the growth of radical ideologies. Drawing on the phenomenological qualitative approach, this study focuses on two pesantrens in Bima, West Nusa Tenggara. This study looks at why such stigmatization on Islamic schools are thriving and what conditions that triggers it. This study shows that the curriculum, exclusive ideologies and traits, and the teaching and learning process of the schools, which tend to indoctrinate, are found to contribute to such a negative stigma to these two Islamic schools.
\end{abstract}

Keywords: Pesantren, Radicalism, Stigmatization, Terrorism.

DOI: http:/ / dx.doi.org/10.20414/ ujis.v21i1.1159

\section{Introduction}

PESANTREN (Islamic boarding school) in general is traditionally recognized as an Islamic education that emphasizes the basic teachings of Islam, such as tawhid (The oneness of God), alQur'an (Holy book), hadith (recorded verbal statements of the Prophet) fiqh (Islamic Jurisprudence), literature and Arabic grammar (nabw) and mysticism (tasamwuf). Islamic boarding schools have evolved since the early penetration of Islam into the archipelago (Indonesia territory). Their historical existence generates the indigenous culture of Indonesia. The fundamental culture of pesantren in Indonesia is open and tolerant. 
Consequently, it brings about the identity and tradition of the pesantren, which is based on the local wisdom where the values of humbleness, openness and solidarity are upheld.

The tradition has long been immerging within the society and the state. There are several factors that lead to the tolerant and open tradition. First, the boarding school is an institution that grows and develops together along with the society. Therefore, social cohesion is strong with the surrounding community. Second, pesantren reflects local cultures. Third, the values and teachings of Islamic boarding school are adaptable to the surroundings, where religious understanding of pesantren adopts the theology of abl al sunnnah wa al-Jama'ah (literally means "the people who follow the examples of the Prophet and are in solid congregation) and with reference to the selection of books (al-kutub al-mu'tabarah) or works of classical scholars from Middle East that tend to be flexible.

The social, cultural, and intellectual capitals of pesantren become the foundation of the education system. The systems and educational pattern derive from an established culture and character although the formation of the latter is the result of a series of processes of cultural assimilation that continuously creates such a pattern. This pattern is the smallest part of the circuit system, while the system is one part of a broader culture. Culture like many major aspects, including other components in pesantren, give effects on the complexity of the system and the existing educational patterns. For example, the open, tolerant, and humble culture can possibly create systems and patterns of education with such characteristics. The pesantren education pattern later becomes the basis for people to accept the existence of Islamic boarding schools as a sphere of religious education in a broader sense.

Throughout its development, pesantren has undergone many changes. Therefore, the pattern of education in the schools stemming from the strong roots in the community has experienced myriad shifts. Lately, Islamic boarding schools have been adhered to the radicalism and terrorism following several attacks accommodated by certain Islamic schools; hence, their initial roles are questioned. Despite doubt from the majority of 
Islamic community, the stigma of the pesantren as radical bases is derived from the alleged linkages between the education pattern of pasantren and several radical and terrorist groups. The changes are prevalent in the elements, culture, and education patterns within the Islamic schooling contexts. To explore the factors contributing to the shifts, this research employs the phenomenological approach as a framework for understanding and expressing the symptoms behind the change.

\section{Islamic Education in Pesantren}

According to Dhofier, Islamic education is still strongly associated with the thoughts of experts in realm of figh, hadith, tafsir, aqidah, and mysticism that developed between the 7th century until the $13 \mathrm{rd}$ century. ${ }^{1}$ Despite the current notion of modern pesantren, there have been a myriad of religious interpretations of different sorts, including the Islamic education systems within the Islamic boarding schooling landscape throughout the history to date.

In addition, the Islamic boarding school education is one of the distinctive intellectual tradition entities; therefore, the education in the boarding schools is characterized by its own culture as the basis for the Islamic scientific development and authentic standards of intellectual genealogy. As an illustration, education and teaching are centered on an ustad (Moslem teacher); education and teaching are based on the literature of classical texts; the relation between religious scholars and santri (Islamic students) are built on compliance and adherence and the establishment of chains of transmission or genealogy science between ustad and santri. This is a general pattern of Islamic education in pesantren. Later, after the arrival of the Dutch education model, the culture of Islamic education in pesantren experience many changes until now.

With regard to the aforementioned tradition of pesantren, a typical pattern of genuine identity of pesantren as an education institution with an Islamic tradition is the role of ustad as an

1Zamakhsyari Dhofier, Tradisi Pesantren, Studi tentang Pandangan Hidup Kyai (Jakarta: LP3ES, 2015), 23. 
educator or kyai (Islamic cleric) as the head of pesantren, while other elements are just as complemented components. So there are three main things that are automatically inherent in the definition of Islamic boarding schools as a traditional education institution. First, mode of understanding of Islam is the dogma and values that is being learnt. The second is the entity and the role of religious scholars. The third is the culture of all forms entailing the Islamic tradition.

To understand the definition of Islamic education in pesantren holistically, it needs to look at the three general patterns, namely traditional Islamic boarding schools embracing the ideology of salaf and modern (khalaf), and a combination of both. However the process of education and culture schools of the third pattern has a very fundamental difference. Therefore, both of these are described separately in this study. The three shades of the boarding school became a horizon and a framework of analysis to the question of the related issue of radicalism within Islamic boarding schools.

More urgent thing in relation to the definition of Islamic boarding school is the existence of a dorm or cottage as an implicit part of the traditional education. The cottage is a place where the santri live and study together under the guidance of a preacher or better known as the ustad and chaplains. Cottage for the santri is a complex environment where ustad also stay. In addition to that, there are also a mosque, classrooms, and other buildings. Throughout its development, Islamic boarding schools are grounded in the figure of a kyai or ustad. Therefore, schools are privately owned by an ustad or endowed by others, and then the ustad becomes the central figure in the boarding school. Pesantren has been carrying out its function for personal and community building. For Indonesians, education is meant to establish independent citizens and state. Through education, a harmonious personality is nurtured and developed. Everyone is expected to gradually regulate life itself, solve problems, meet needs and control and direct their lives. ${ }^{2}$

${ }^{2}$ M. Dawam Rahardjo and et. al., Pesantren dan Pembaharuan (Jakarta: LP3ES, 1995), 23-25. 
The role of pesantren education as proposed by Rahardjo above is one of the pesantren education patterns that does not only play role as guidance for Muslims but also attempts to bring about social change and improvement. Therefore, the influence of pesantren is prevalent in both the lives of santri and alumni and surrounding communities. It can be proven by the role of ustad as a leading scholar not only within the school but also in the communities.

Naquib Al-Attas defines the goals of Islamic education as a vehicle that not only trains the mind, but also promotes the potentials of mankind; therefore, Islamic education has implications for teaching or transmitting knowledge and training santri as a whole. With this regard, ustad acts not only as teachers (mu'allim) who transfer knowledge, but also educators (murabbi) who train the soul and personality. Based on the objectives of Islamic education, the Islamic community themselves believe that Islamic education in pesantren has been considered a model of education institution which has the advantages to either the tradition or culture of science, or on the internalization of moral of Muslims. ${ }^{3}$

In this regard, Dhofier ${ }^{4}$ explains that among the many purposes of Islamic boarding, educating individuals to be independent and reliant solely on God (Allah) is of primary aim. Ustad usually pay attention on the development of strong individual characteristics. The santri are educated in accordance with their capabilities and weaknesses so that the development of diverse skills is actually emphasized in the Islamic tradition as a speech and debate skills. Santri are taught to be obedient and responsible for preserving and preaching the knowledge and devoting their time and energy to lifelong learning.

\section{Relation between Ustad and Santri}

There are two types of santri in the realm of traditional boarding schools, namely santri mukim and santri kalong. The former is the santri who comes from remote areas and stays in

${ }^{3}$ Syed M. Naquib Al-Attas, Filsafat dan Praktek Pendidikan Islam (Jakarta: Mizan, 2003), 124.

${ }^{4}$ See Dhofier, Tradisi Pesantren, 35. 
the schools. The santri mukim whose longest stay in boarding schools typically constitutes a separate group that is responsible for taking care of the interests of schools every day. On the other hand, santri kalong is the santri who comes from the villages around pesantren and usually does not settle in the school. To follow the lessons at the pesantren, the santri can return (ngelaju) to their home. ${ }^{5}$

In this study, the learning process of santri mukim is considered as part of the academic culture of pesantren because they live and learn in the boarding schools. Based on the elements mentioned by Dhofier, the pesantren, such as the scholarly tradition of Islamic schools, cannot be separated from the five elements. Each component has a structural relationship to each other which can be explained even though Dhofier does not explain how the five elements of pesantren education are related to one another, especially the relationship between the ustad and santri. All of these elements are united and centered in the boarding schools. Such relation structure interaction results in the birth of unique values, such as compliance and adherence to the ustad, tawadu (humble) attitude, purification prior to learning and respect for science, all of which then turn into an "obligation" that are prevalent in the academic tradition.

One relationship between multiple elements that can be described in this study is the relationship between an ustad and a santri in the learning process as a part of academic culture in the pesantren. The relation derives from the power of ustad as a figure that influences the learning objectives of the santri.

The culture and structure relation between religious teachers and santri is important to probe in this study, as it relates to the pattern of spread and transforms values that are considered radical. The transformation of values and ideology has been considered to easily go through a relationship that is built between the cleric and the students. A relation into the access space for the process of indoctrination is carried out by the cleric. The existence of the ustad as a role model for all santri allows the imitation process performed by santri. As such is closely

5Ibid., 37. 
related to the existing role-model in the immediate environment such as boarding schools, schools, and households. The process of imitation in such instructional landscape described by Urie Bronfenbrenner, quoted by Berns, as the following

Modeling is a form of imitative learning that accrues by observing another person (the model) that perform a behavior and experience its consequence. It enables us to learn appropriate social behavior, attitude, and emotions vicariously. ${ }^{6}$

According to Berns, the definition of modeling is a study in the form of mimic, and this happens through a process of observation of the behavior and experiences of others. That is formal or informal interaction between santri with an ustad in a boarding school environment, which supports the process of imitation and adoption patterns of thought and behavior directly or indirectly. Such academic tradition brings about the possibility of excessive reliant on the ustad, which may encourage people to be fanatic and taqlid (blind imitation) in knowledge. Consequently, this promotes blind imitation excessively in the form of attitude on one hand and the loss of critical power on the other side.

Related to the transformation value through role models, Berns said that "...... Children identify with role models and imitate behavior. The role models can be peers or teachers. For example a child who has been attending school for a while may home and display some behavior". 7 The manner of the ustad in a boarding school is a source model for any santri dwelling in the boarding school, causing imitation behavior. On the other hand, the pattern of the unique relationship between the santri and chaplains in the culture of traditional Islamic education is another form of a method of regenerating natural scholars. This is evidenced in the history of boarding schools in Java, especially in the 20th century. It appears that the majority of pesantren and ustad scattered the island of Java and perhaps beyond the island,

6Urie Bronfenbrenner, The Bioecological Model of Human Development (New York: National Academy Press, 2006), 125.

${ }^{7}$ Urie Bronfenbrenner, The Ecology of Human Development: Experiments by Nature and Design (Cambridge, Massachusetts, and London, England: Harvard University Press, 1979). 
which may be a result of penetration of Tambak Beras pesantren in Jombang established in $1830 .{ }^{8}$

According to Dhofier, Tambak Beras Jombang pesantren led by Kyai Sihah is a genealogy of the emergence of networking ustad and Islamic boarding schools scattered around Java. One lane penetration schools and ustad are developing a tradition of transmitting knowledge and intellectual link between fellow ustad and their families. Thus, the existence of networks of schools and ustad is a form of cultural and religious heritage built by a Kyai in pesantren education.

\section{Education Patterns of Pesantren}

A pattern is a form or a model (or, more abstractly, a set of rules) that can be used to make or to produce any or part of something. ${ }^{9}$ Patterns can also be called a system, how to work, and or forms (fixed structure). If related to education, the pattern is a form of organizing programs and learning activities to be presented to santri by pesantren. Thus, the pattern of pesantren education is that it has a sense as a teaching model that applies in the pesantren. In addition, if it is associated with the pattern of thinking can mean as something that is received by a person or group and is used as a guide deriving from the surrounding environment. Education is a process of transformation of knowledge moving towards improvement, reinforcement, and improvement of all human potentials. It implies that understanding the pattern of pesantren education is a system, method or form of work that maintains, nurtures, educates, and guides santri in accordance with the purpose of the boarding school.

With this regard, the specific pattern of pesantren education is the educational activities that have become routine and repeated to form a certain model. In other words, the pattern of pesantren education is a routine that has become the characteristic of education in Islamic boarding schools. Therefore, this pattern is not something that exists suddenly, but it comes consciously or

8Dhofier, Tradisi Pesantren, 231.

Wikipedia, September accessed 9, 2016, https://id.wikipedia.org/wiki/Pola. 
not, and is formed through a long process. Patterns in pesantren education are identified through models of simplicity, transparency, and independence in the learning process. Although pesantren has many variants, traditional pesantren education in general has the same pattern in education and teaching. Nevertheless, a pattern may be changing with the purpose of boarding education institutions. In boarding schools, there are patterns of behavior commonly accepted as the pattern of education. From a cultural standpoint, the same pattern of education is also called cultural patterns (culture pattern), that is also coercive, such as law, due to repetition, and that is patterned into something mechanical without the will or consciousness.

\section{Radicalism and Islamic Education}

Since the widespread issue of terrorism, the definition of radicalism has been associated to terrorism, which connotes a pejorative meaning. As a result, the term radicalism becomes negative to date although theoretically the two words have very different definitions. In addition, the term radicalism has a positive meaning, as described by Esposito, that radicalism means tajdid (renewal) and reconciliation (repair), a spirit of change for the better. ${ }^{10}$

The word radicalism is more frequently liked to the term fundamentalism. For some Islamists, Esposito argues that fundamentalism is a preconceived notion of Christian and Western stereotype, which also implies a monolithic threat that never exists. According to Esposito, a general term that is more suitable in fact is the "Islamic renaissance" or Islamic activism" unencumbered by values rooted in the Islamic tradition. Islam has a tradition of tajdid and reconciliation which includes the idea of political and social activity since the beginning of Islam until now. ${ }^{11}$ Therefore, Esposito preferred to use the term Islamic resurgence and activities than the term of radicalism or fundamentalism. In this study, the strong suspicion that the

10John L. Esposito, Ancaman Islam Mitos atau Realitas, Edisi Revisi: Menggugat Tesis Huntington (Bandung: Mizan, 1996), 1-4.

${ }^{11}$ Ibid. 
radicalism associated with the boarding school during this time, according to researcher, is another form of genealogy of Islamic renaissance on a small scale; although for some people and the government, it is a case to worry about.

The term radicalism refers to the radical views about certain groups, their principles and ideas. Consequently, it is understood that radicalism is rooted in the minds and beliefs of groups or individuals about the ideas and beliefs that are considered true. If it is associated with Islam, it will be a radical Islam or Islamic radicalism, meaning that a group of Muslims who embrace such a radical perspective.

Ideas and thoughts that are often considered part of the struggle of radical Islamic groups, among others, are the establishment of the Islamic shariah (Islamic law) and governance based on Islam (Khilafah Islamiyah), and jihad fisabilillah. These views belong to some radical Muslims, which will be described separately in this study.

The negative connotation of radicalism makes it difficult to establish a good relationship between Islam as a religion, whose etymological meaning stems from the word for "peace", and radicalism or fundamentalism as an ideology with negative connotation (pro-violence). Today, the growth of Islamic radicalism is increasingly viewed or labeled as terrorist groups.

The mixture of the issue of terrorism and radical Islamic term impact on the way people perceive Islam, meaning that when the so-called radical Islam is used, it is understood that a group of radical Muslim or group of Muslims commit terror. The biased interpretation tends to be a massive confidence today. For example, Millar stated that "radical Islam will be defined as an Islamist movement that seeks to use violence or violent rhetoric to gain power with the goal of creating an Islamic state, based on the shariab". 12 According to Miller, there are two characteristics of radical Islam in terms of the objectives: using violent means to achieve its objectives and to establish an Islamic state or to apply Islamic shari'ah (Islamic law) formally.

${ }^{12}$ Reuben Miller, "The Literature of Terrorism," Terrorism 11, no. 1 (January 1988): 63-87. 
While according to the Center for the Study of Islam and Society of Jakarta Islamic State University, there are four criteria that an Islamic group can be categorized as embracing the radical traits. First, it has a high ideological and fanatical conviction for the values championed to replace the value system as a status quo. Second, the process and approach often used is often harsh. Third, in terms of the socio-culture and religion, the radical groups have strong community ties and display a typical personal appearance. Fourth, radical Islamic groups often move secretly although some may be in an open way. The aforementioned criteria accord with the basic meaning of radicalism that is, as an ideology that intends a change or renewal of the social and political overhaul drastically by means of violence. ${ }^{13}$

These criteria cannot always be the standard measures to gain a better understanding of the actual concept of Islamic radicalism. As seen in the community, behavior and radical ideologies are so contagious or internalized in the life of a group or a person. Internalization occurs through a process of radicalization directly or indirectly. As stated by Wilner and Dubouloz:

Radicalization is a personal process in which individuals adopt extreme political, social, and/or religious ideals and aspirations, and where the attainment of particular goals justifies the use of indiscriminate violence. ${ }^{14}$

Changes of individual or groups from being radical to tolerant cannot be detected easily because the early stages of radicalization spark through their thoughts and psychological turmoil. Therefore, it is always difficult to accurately define whether a person or groups are radical or not. On the other hand, in the discourse of political Islam, the term Islamic radicalism comes in a variety of interpretations. For example,

${ }^{13 N u h r i s o n ~ M . ~ N u h, ~ P e r a n a n ~ P e s a n t r e n ~ d a l a m ~ M e n g e m b a n g k a n ~ B u d a y a ~}$ Damai (Jakarta: Puslitbang Kemenag, 2010), 11.

${ }^{14}$ Alex Wilner and Claire-Jehanne Dubouloz, "Homegrown Terrorism and Transformative Learning: An Interdisciplinary Approach to Understanding Radicalization," Global Change, Peace \& Security 22, no. 1 (March 10, 2010): 38. 
Esposito equates Islam with radicalism or fundamentalism as neo fundamentalism, Islamic revivalism (Islamic renaissance). ${ }^{15}$ In addition, Roy views that Islamic radicalism is the contemporary Islamic movement that tries to think of Islam as a political ideology which covers the whole of social life. ${ }^{16}$ As a consequence, according to Roy, the presence of Islamic radicalism is a form of confrontation against modernity, which has been accepted involuntary.

Mbai, a former National Chief of Counter Terrorism, argues that "groups of Islamic radicalism in Indonesia have established an extreme movement in the name of religion. The ideology of radicalism is at the root of terrorism, a narrow understanding regarding a creed, religion, creating a conflict so be terrorized". ${ }^{17}$ Mbai shows that Islam as a religion teaching spirituality and values of universal goodness, which is often a tool of justification and is used for a group of people in achieving the goals. Esposito argues that radical Islamic movement, as a form of renewal and Islamic awakening to the changes in accordance with the teachings of Islam, is considered pristine. Additionally, they put the teachings of Islam as something positive.

The basic meaning of the term Islam is basically positive; for example, Islam has a lot of meanings, such as "peace" and "submission". In "The Venture of Islam", Hodgson describes that the term "Islamic" refers to the inner spiritual shape of a person of good will. The word Islam means submission to God. Therefore the word Muslim means those who give themselves is a form of participant. Clearly, this means accepting personal accountability for the norms of action which is seen to have transcendent power. ${ }^{18}$

In addition, the word 'radical' also has a lot of meanings, which include "basic" and "root". Hence, drawing on the

15Esposito, Ancaman Islam, 21.

16Oliver Roy, Geneologi Islam Radikal, ed. Ali Noer Zaman, trans. Narullah Ompu Bana (Yogyakarta: Genta Press, 2005), 25.

${ }^{17}$ Ansyaad Mbai, Dinamika Baru Jejaring Teror di Indonesia (Jakarta: AS Production, 2014), 15.

${ }^{18 \mathrm{M} a r s h a l l ~ G . S . ~ H o d g s o n, ~ T h e ~ V e n t u r e ~ o f ~ I s l a m, ~ I m a n ~ d a n ~ S e j a r a h ~ d a l a m ~}$ Peradaban Dunia, trans. Mulyadhi Kartanegara (Jakarta: Paramadina, 2002), 101. 
definition of the word Islam and radicalism, it can be described that the meaning of radical Islam is "people who are strong" or "those who cling to the basic teachings of Islam". According to Hodgson, the attitude in individuals is a form of personal acceptance of the ideal piety. ${ }^{19}$ So the definition of the radical Islamic group is a collection of people who obey the commands of Islamic religion totally and powerfully. These definitions are different from radical Islam from the perspective of the West, which is often associated with a radical Islamic group. Nevertheless, this paradigm is constructed and becomes a stigma of Islamic groups for a long time until today. This view believes that radical Islamic groups or Islamic fundamentalism has its own space and identity in the history of the development of Islam in general.

Many Western scholars believe that the radical Islamic group is inspired by the teachings and commands radically or fundamentally rooted in the Qur'an and Sunnah, such as jibad, syariah law, economics, politics, leadership, the concept of ummah, and the others. These concepts are difficult to deny because they are found in Islam. The basic concepts are the philosophical and practical foundations for Muslims to live a life, although until now for most Muslims these concepts still differ in interpretation and implementation.

In further developments, there are some growing radical Islamic groups that try very hard to defend and fight for ideas and ideologies that they claim to be true. Like the classic Islamic radical groups represented by the Khawarij, Wahabi, and modern Islamic radical groups like the Muslim Brotherhood, Jamaah Islamiyah, Al-Qaeda, ISIS until now. Some groups are suspected of contributing to the development of radical Islamic groups that are widespread today.

The factual issue of radicalism is not only present in Islam but also may arise from any religious group. Some Western thinkers said that the phenomenon of the war against terrorism is indeed not only a reflection of radicalism but also clashes between radical groups as disclosed by Tariq Ali in The Clash of

${ }^{19}$ Ibid. 
Fundamentalism; Crusades, Jihads, and Modernity, as clashes between American radicalism in this case the Bush government and the global radical jihadist, Osama bin Laden. ${ }^{20}$ Even Ali said that American imperialism is the mother of radical group. This is in accordance with Esposito, who states that such role played by American results in the reaction of the Islamic groups to reject the concept of democracy, human rights, secularism, capitalism, modernity, and others. These views are in line with what is disclosed by F. Fukuyama, that the events of September 11 was an attack on modernity based on a rejection of Western values such as homosexuality, permissiveness, and the freedom of women and others. Nonetheless, the view connecting these groups with the emergence of Islamic radicalism today is an assessment which must be viewed critically.

\section{Two Tales of Islamic Schools in Bima: Pesantren $U$ and $M$}

Initially U Islamic School (abbreviated as UIS) under the auspices of $\mathrm{M}$ Foundation was headed by cleric TQ, which is now a member of UA faculty in the village of $\mathrm{O}$ in Dompu. The leadership of the school was raised by $\mathrm{AB}$, previously suspected as a member of Jama'ah Ansorut Tauhid (JAT) led by cleric Abu Bakar Ba'asir. Since the incidence of bomb cases blasted at the cottage U and found some sharp objects on the July 112011 at 15:30 pm, killing cleric F, the boarding school has been suspected by the police as a radical institution of religious education. It was even accused of being a base of terrorism. As a result, the head of this school was arrested. Although UIS denied all allegations exposed by the police, the issue of the involvement of this school with terrorism was so strong and widespread in the community.

Following the explosion, most of the buildings were flattened to the ground. The students and some clerics were still traumatized by the explosion. Moreover, the documents and data of administration of the students were burned down. Even a growing issue in the public is that the pesantren would be closed

${ }^{20}$ Tariq Ali, Benturan Antar Fundamentalis, Jihad Melawan Imperialisme Amerika (Jakarta: Paramadina, 2004), 342. 
although the fact is not. According to the boarding school manager, the school will be reestablished with a new name. The case against UIS has impacted adversely on other boarding schools, such as the Islamic boarding school $\mathrm{M}$, which is in the same region, only one village away from UIS. The ideology and management of both schools have in a lot in common. This is the reason for the police to continue to monitor the presence of both schools. In terms of education, the background for the establishment of the boarding school $\mathrm{U}$ is actually not much different from M Islamic School (abbreviated as MIS), which aims to produce preachers who cling to the Qur'an and Sunnah with the spirit of jihad as a way to broadcast Islam in Bima. In addition, reason that encourages the establishment of such schools is the awareness to purify aqidah (monotheism) or community and strives to enforce shariab law in Indonesia. The awareness to enforce Islamic law makes thinking and educational activities that exist in the pesantren are not aligned with the Indonesian state ideology.

On the other hand, internal purpose of the ideological struggle of the founders and managers of the boarding schools are training the generations to implement the teachings of Islam and enforce Islamic shariah as a whole. Therefore, since its establishment 12 years ago, the existence UIS has been highly autonomous in terms of funding, curriculum, management, teaching systems, and leadership. UIS does does not accept and ask for help from any agencies, including the government. As a result, the schools are managed independently by the managers. This means that this pesantren is purposely designed for specific purposes and limited to certain circles. For example, children who enter at the schools are not oriented diploma. That is why, the schools do not issue boarding school diploma. Pupils at this school only aim to deepen their study on the Qur'an or Islam (da'wah and jihad) and the Arabic language in accordance with the methodology of the salaf.

Based on the methodology of da'wah wal jibad to uphold the Qur'an and the Sunnah of the prophet, the school was founded. Therefore, to maintain the purity of simultaneously achieving educational goals in the process and methodology of the 
context, the manager of the curriculum of the schools does not involve the government. One of the consequences of such management is, since its foundation in 2004 until today, that it does not have legal standing like other boarding schools in general. Consequently, when the explosion occurred at this school in 2011, the government judged that the pesantren was not an Islamic boarding school. This is supported by the recognition of the chairman of the Pesantren Forum of West Nusa Tenggara Tuan Guru Sofwan Hakim, that pesantren like UIS is not purely pesantren. The reason is that the school allegedly teaches violence on behalf of Islam.

In contrast to the above opinion, one of the administrators, $\mathrm{SB}$, a cleric in the boarding $\mathrm{U}$ says that "our school is a pure boarding school with the emphasis on the da'wah wal jihad in the district, Bima. There has not been a connection with the teachings of such misleading allegations over the years. This pesantren had to open up to anyone who wants to learn it. ${ }^{21}$ Referring to this view, it is clear that UIS has an open attitude because the enforcement of Islamic law in society must be done openly so that the goal can be achieved through a friendly propaganda. All managers of UIS claim that the ideology and religious attitude are very open. As the author observed, it is found that that the pesantren has a vision to enforce Islamic law in Indonesia through preaching mission openly.

While the establishment of MIS cannot be separated from four people namely MY cleric, cleric JB, BE cleric and cleric T. They see an ill portrait of the society, who left the culture of Bima as a true identity of Islamic culture since the beginning. However, throughout the time, the Islamic culture in Bimanese community began to be replaced by the modern culture that dominates the current era of globalization. Realizing this, BE cleric and his colleagues sought to establish an alternative education or pesantren as a place for Muslims and as the field of Islamic propaganda. With this regard, in 2001, the clerics founded the village $\mathrm{N} \mathrm{M}$ in the District B-Bima and choose MY

\footnotetext{
${ }^{21}$ Interview, September 9, 2015.
} 
as a chairman of the Foundation first with a major focus on reading and recitation of the Qur'an. In addition, as a seedbed basic of Islam, M Foundation became a gathering place for the propagation of Islam-leaning activists salaf, which is now known as Jamaat Ashorut Sharia (JAS) organization.

The organization promotes salafim which aims to encourage true monotheism and faith and to practice Islam as exemplified by the Prophet and the early pious generations of Islam. Moreover, the goal is to convey and disseminate ideas or understanding of religious pattern of salaf. It later became the embryo or embryo of the establishment of MIS, which is now in the village $\mathrm{T}$. The presence of this school is not easy, requiring a long tiring struggle to make it happen. On the other hand, MIS is known to be very close and even parts of UIS. Therefore, the two schools have a similar ideology. Consequently, MIS M until now is stigmatized as radical pesantren.

\section{Radical Elements}

In general, both of the Islamic boarding school patterns in this study are not much different from other traditional pesantren (Salaf) where they have a lot in common in terms of culture, system, and education pattern. Salaf education culture is the education that is based and oriented towards the traditional religious understandings of Islam based on the classical texts of early Islamic scholars. The system is a typical form of teaching carried out in pesantren salaf as sorogan, bandongan, ta'lim, and balaqah. The shape of the pattern of education is a model of the educational process carried out to achieve the goal, for example, the patterns of authoritarian education, indoctrinate, dialogue, and exclusivist.

The similarity of the patterns, system, and culture of education could be characteristics inherited to traditional Islamic identity which is widely known by the public. The pattern of traditional education has been believed to have an impact on moral education, religious knowledge development, and cultivation of strong values to the santri, so that it promotes the Islamic character building. Heterogeneities of several goals and boarding schools have an impact on changing patterns, system, 
culture and education that are implemented. One example is the change in the pattern of traditional pesantren education, which was originally open, tends to be exclusive. However, such a notion of pesantren grows lately, cannot always be interpreted as a form of radicalism.

During this time, the allegation of radicalization process in boarding school is still political and ambiguous. As a consequence, it is not easy to justify a particular boarding school as disseminating radical thoughts or not. This use of radical category or classification in this study connotes negative and pejorative meaning. This is necessary in order to avoid bias in articulating the terms of radicalism. Radical pesantren education pattern can be understood by knowing the characteristics of a traditional boarding school in general. There are several simultaneous characteristics indicators of traditional pesantren. Here is a table of the characteristics of traditional Islamic views on some aspects related to this study.

Table 1 Characteristics of the two traditional Islamic boarding schools in Bima and other mainstream Islamic boarding schools in general.

\begin{tabular}{|c|c|c|}
\hline Aspect & Pesantren $\mathbf{U}$ dan $\mathbf{M}$ & $\begin{array}{c}\text { Pesantren Salaf } \\
\text { Tradisional) in General }\end{array}$ \\
\hline $\begin{array}{c}\text { Type of } \\
\text { religious } \\
\text { understanding } \\
\text { and literature }\end{array}$ & $\begin{array}{l}\text { 1. Ahlul Sunnah Waljama'ah } \\
\text { (ASWAJA) base on aqidah } \\
\text { (Abu al Hasan al Ash'ari), } \\
\text { Ibn Taimiyah, Muhammad } \\
\text { Abduh, Muhammad Ibn } \\
\text { Abdu Wahhab, Hasan al } \\
\text { Banna, dan Sayid Quttub }\end{array}$ & $\begin{array}{l}\text { 1. Ahlul Sunnah } \\
\text { Waljama'ah } \\
\text { (ASWAJA) base on } \\
\text { aqidah (Abu al Hasan } \\
\text { al Ash'ari), tasawuf } \\
\text { (Imam Ghazali), and } \\
\text { Figh (Imam Syafi'i) }\end{array}$ \\
\hline $\begin{array}{c}\text { formal } \\
\text { curriculum and } \\
\text { bidden curriculum }\end{array}$ & $\begin{array}{l}\text { 1. Aqidah Islamiyah (tawhịd) } \\
\text { 2. Syariat Islam } \\
\text { 3. Fiqih Jihad (chapter } \\
\text { abkamuddimah) } \\
\text { 4. Arabic } \\
\text { 5. Ushul Fiqh } \\
\text { 6. Nahwu, Shoraf } \\
\text { 7. Tafsir } \\
\text { 8. Hadits, etc. }\end{array}$ & $\begin{array}{l}\text { 1. Arabic } \\
\text { 2. Ushul Fiqh } \\
\text { 3. Nahwu, Shoraf } \\
\text { 4. Tafsir } \\
\text { 5. Hadits } \\
\text { 6. English } \\
\text { 7. Exact and natural } \\
\text { science }\end{array}$ \\
\hline $\begin{array}{l}\text { Patterns of } \\
\text { Education }\end{array}$ & $\begin{array}{l}\text { 1. Authoritarian } \\
\text { 2. Hegemonic }\end{array}$ & $\begin{array}{l}\text { 1. Semi Authoritarian } \\
\text { 2. Flexible }\end{array}$ \\
\hline
\end{tabular}




\begin{tabular}{|c|l|l|}
\hline Aspect & \multicolumn{1}{|c|}{ Pesantren U dan M } & \multicolumn{1}{|c|}{$\begin{array}{c}\text { Pesantren Salaf } \\
\text { Tradisional) in General }\end{array}$} \\
\hline & $\begin{array}{l}\text { 3. Indoctrinate } \\
\text { 4. Rigid } \\
\text { 5. Exclusive } \\
\text { 6. Provocative }\end{array}$ & 3. Inclusive \\
& 7. Truth claim & \\
\hline Teaching & 1. Classical & 1. Classical \\
system & 2. Sorogan & 2. Sorogan \\
& 3. Bandongan/weton & 3. Bandongan/weton \\
& 4. Halaqah & 4. Halaqah \\
\hline Culture of & 1. Traditional & 1. Traditional \\
Pesantren & 2. Independent & 2. Independent \\
& 3. Exclusive & 3. Inclusive \\
& 4. Promoting Fanaticism & 4. Tawassut (the hands- \\
& 5. Ghuluw (excessive / & middle) \\
& 6. Religious & 5. Tawazun (balanced) \\
& 6. Moderate \\
\hline
\end{tabular}

Source: Analysis of field data comparison of traditional pesantren $\mathrm{U}$ and $\mathrm{M}$ with a traditional boarding school in general (2016)

Based on the above data (see the table 1), there are many differences between UIS and MIS and and other traditional pesantren in general although they have some similarities. The difference stems from the type or style of religious understanding and sources, which have implications on other aspects, such as educational patterns, systems, and culture of the pesantren. Based on table 1, the Islamic education pattern of UIS and MIS tend to advance radicalism.

\section{The Curriculum}

Curriculum in this study is placed as part of a boarding school environment. Often the curriculum at the school is alleged as the basis for the development of their values even though the assumptions are not entirely correct. The curriculum content is one aspect that can be used as an indicator to see the elements of radicalism in the schools.

The pesantren curriculum in general is an element that is extracted and later developed on the pattern of the religious understanding of Ablus Sunnah wal Jama'ah (Aswaja). Understanding Aswaja is the epistemological foundation to 
construct science taught in the boarding schools. With this regard, Abdullāh bi 'Abd al-Hāmid al-Athari views that understanding Aswaja in Islamic tradition has been translated into three pillars, namely in the field of aqidah, adopting the thought of Imam Abu Hasan al-Asyah'ari; in the field of Sufism, leaning towards Imam Abu Hamid al-Ghazali; and in the field of figh, following Shafi'i. ${ }^{22}$ While the ustad of both UIS and MIS tend to understand Aswaja with reference to the interpretation of the scholars who came later as, Hasan al-Banna, Abu A'la alMaududi, Sayyid Qutb, Muhammad Baqir al-Sadr, and Sa'id Hawa, Muhammad Abduh and Muhammad ibn Hambal despite basing their ideology on earlier scholars. Scholars in the context of global politics tend to be regarded as scholars affiliated to the radical religious thoughts.

Both versions of Aswaja ideologies have differences in some respects, for example, in the interpretation of jihad in the Qur'an. For the early scholars, jihad has many meanings, one of which is "serious in terms of goodness," while for other scholars who came later (contemporary), tend to interpret "struggle for Allah by sacrificing wealth and soul" including the application of Islamic law in life. ${ }^{23}$ The differences in terms of the interpretation and conceptualization have implications on diverse religious practices. Therefore, referring to the foundation epistemology, the adopted curriculum developed by the ustad in UIS and MIS revealed that they have a radical tendency.

Epistemology of philosophical foundation curriculum or the curriculum is not the only determinant factor that may bring about the notion of radical on a pesantren or not. There are still many other factors. For example, the relationship between the schools and the surrounding community, and the relation with the public schools, can be an indicator for the presence of radicalism in schools. Moreover, content of pesantren curriculum content is closely related to people's needs. Generally, in the traditional Islamic educational institutions, the material of fiqh gets a more dominant portion as it provides the problem solving

22‘'Abdullāh bi 'Abd al-Hāmid al-Athari, Aqidah Salaf; Ablul Sunnah wal Jama'ah (Jakarta: Pustaka al-Inabah, 2015), 35-37.

${ }^{23}$ Ustad M, interview, 12 September 2015. 
directly to the community. The reality shows that the existence of traditional boarding schools is not subject to the demanding needs of the surrounding community. The opposite occurs in suspected traditional Islamic radicals which normally tend to distance themselves from society where they live in. The fact is that the two suspected radical schools tend to be different from the ideology, values, and cultures of the surrounding communities. These sorts of schools do not have emotional bound with the surrounding communities and strong social ties between the two.

Pesantren which tend to be radical is built to introduce the ideas and ideology of Islam that have been constructed by the owner of the pesantren, so that these institutions tend to be sensitive to social problems and the culture of the society. Pesantren like this are usually closed to the surrounding environment with more exclusive religious understanding, which never involve people in activities. As a result, conflicts are vulnerable between the pesantren and the people around them due to their social and ideological gap. The condition shows that the pattern of traditional Islamic education today is no longer homogeneous as in the early days. Therefore, it is not easy to make a single stigma against pesantren. Nevertheless, it is not likely that Islamic boarding schools having radical views and becoming a center of terrorists have a radical network with terrorist groups beyond pesantren.

On the other hand, heterogeneity of the boarding school education is not only concerned with ideology, methods, knowledge, and the destination but also the implemented curriculum. UIS and MIS, for example, are among the pesantren that experienced the growth and changes, so that they have differences with other traditional pesantren. As an illustration, in addition to teaching fiqh toharah materials, fighi prayer, and fiqh muamlah, the schools also teach the fiqh of jihad until chapter abkamudimmah. It is very different from traditional boarding schools in general which only teach figh related to worship, fiqh muamlah and so on. Nevertheless, their teaching jibad should not be associated with radicalism or terrorism because of the issue of jihad, including the fundamental teachings of Islam. 
The material aqidab Islamiyah (tawhịd), for example, is to strengthen the faith and Islam at the same time denying syirik against something considered taghout. The law relating to Islam is practiced, while jihad is related to the way to fight and defend the teachings of Islam. Consequently, the two boarding schools emphasize the spirit of understanding aqidab Islamiyah, so that the santri are expected to implement a pure Islamic law. Therefore, any form that may harm the pure understanding of Islam itself must be resisted and removed. Islam must be put forward so that the path of jibad fi sabilillah should be chosen to uphold and defend Islam. It is surprising that each santri holds the teachings that encourage "bubbul maut fi sabilillah" and "bubbul dunia wa karobiatul maut". These explanations provide an understanding that each traditional boarding school has different orientation in education. As an example, there are schools that emphasize memorization of the Qur'an, the emphasis on the ability to read the kitab kuning (the books of early Islamic scholars), or on Arabic language skills, and the ability of proselytizing, and others. The diversity of the orientation of the output is closely related to the formulation of the curriculum that will be taught.

UIS and MIS have equally emphasized on the teaching and preaching monotheism, jurisprudence, jibad, and shari'ah law enforcement although not all of these three materials described in detail in the structure of the subject matter. In other words, they are delivered in the form of bidden curriculum. Because both Islamic boarding schools are traditionally patterned, there have many similar aspects to those of traditional pesantren. For instance, it rests on the view of Dhofier (2015), who states that the curriculum of traditional Islam refers only to the classics thoughts where the overall classical books are classified into eight groups, namely Nabwu, Shoraf, Fiqh, Usul Figh, Hadith, Tafsir, Tawhid, and Taswuf. The books cover a very short text to the voluminous text bold, with a teaching system sorogan, bandongan, and balaqah. ${ }^{24}$

24Dhofier, Tradisi Pesantren, 24. 
Specifically, there are some curriculum orientations at UIS and MIS that include: (a) adherence to the values of monotheism, where santri are expected to have an awareness of Allah as the only God worthy to be worshiped and obeyed and believe that no deity except Allah. With the awareness, the santri must believe and carry out the laws that have been set by Allah as a form of obedience to Allah, (b) the spirit of jibad, in the perspective of both the boarding jihad is a duty for every Muslim. Therefore, high morale in the defense of Islam is internalized in each santri, (c) foster an attitude ukhwa Islamiyah, where santri have an awareness of the importance of brotherhood on the basis of faith, (d) nubuwat (the teaching of the prophet), where the santri are expected to emulate the behavior exemplified by the Prophet as foundations on which to build an Islamic character.

\section{Interaction between Ustad and Santri at UIS and MIS}

The ustad as a role model or a model that can be observed directly by the santri is an important factor in shaping education. This means that in learning interactions, an ustad not only acts as a transformer of religious knowledge in itself but also as a role model as well as a motivator in shaping the character of the santri. At the same time, the role consciously or unconsciously forms the repetition of typical patterns in education in the boarding schools. Thus the process of interaction between the ustad with the santri not only showed the relationship between the phenomena of mere personal but also the significant meanings and values related to the educational process.

Furthermore, the motivating force in shaping the character of the ustad is reflected in the relationship and treatment given to ustad against santri in a boarding school environment. For the students of UIS and MIS, the ustad is not only as a teacher who should be honored, but also as parents who are always there in the learning environment and the lives of santri. The condition is supported by the presence of the ustad who lives in a boarding school environment, so this certainly encourages the process of intense interaction between religious teachers and santri. 
On the other hand, the intensity of the interaction of santri with the ustad allows the transformation of hidden curriculum to be more effective. Moreover, these interactions are built on mutual trusts and a high respect among santri and ustad, thereby, building a very strong emotional bond. Often the emotional bond is reflected in the santri excessive bigotry against the ustad. It is then supported by the culture of pesantren education. Referring to the view of the ustad $\mathrm{M}$ as treasurer of the pesantren, that during this time the ustad considers these santri as his own children, where the ustad is not only to educate but also to find new donors and help meet the daily needs. The condition shows that the interaction is not limited to the learning process but in a broader life ${ }^{25}$. Here is a simple illustration of how the interaction between the elements of pesantren relate to one another.

Figure 1 Relationships and Interactions among Elements in Pesantren

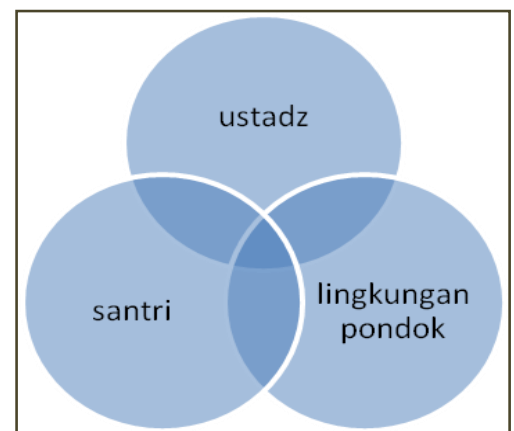

Source: Adapted and developed from the concept of Pesantren elements

Dofier (2015)

Figure 1 illustrates how the existence of santri is strongly influenced by surrounding elements, even if it refers to the views of Dhofier. There are five elements of traditional boarding schools that cottage, mosques, teaching kitab kuning, religious scholars, and santri. Nevertheless, the views of the aspects experience direct interaction with each other. In this study, only the boarding element is divided into three, namely the ustad, santri, and the environment of boarding school. While the existence of other elements such as mosques, kitab kuning go into an integral part of the boarding school environment. The relationship and interaction between santri and an ustad who are

${ }^{25}$ Ustad M, (Interview 08.12.2015), 
touching each other, as shown in Figure 1, shows that the santri are entities that are directly related to the life of the ustad through the process of imitation and modeling. On the other hand, the ustad is an entity that acts as the as teachers, parents, counselors, as well as peers group of the santri.

Based on perspective of symbolic interactionism, the interaction between the santri, religion, environment shows that boarding schools as a whole micro social significance. The theory sees every object in the form of action or symbol as part of the special importance of communication between santri with an ustad. Therefore, any form of interaction carried out by an ustad is supposed to have goals and interests. In the context of this study, the benefit is a transformation in understanding religion or ideology owned ustad and santri.

After a transformation in understanding religion or ideology, these interactions form a common bond understanding of something valuable and ideology considered true among members of a social group in this case religious teachers and santri. It rests on the Jurgen Habermas' view that measures ${ }^{26}$ multiple actors (religious teachers and santri) using the mechanism of achievement of understanding. Comprehension question is how such measures can be established in boarding schools, that is, the relationship between the three elements as in Figure 1 form social relation that reveals the meaning. Because "an action" will be called an act of "social" when explaining the behavior of others, or in other words an action orientation is influenced by the behavior of others.

Based on Weber's view, there is a requirement that something can be called the social interaction if (a) an orientation toward others act of subject's behavior, and (b) a relation of reflection orientation acts as reciprocal actions of several subjects. ${ }^{27}$ Referring to these criteria that the interaction between religious teachers, santri, and the environment have a significant meaning. This is related to Habermas, who refers it as

${ }^{26}$ Jurgen Habermas, Communication and the Evolution of Society (Boston: Beacon Press, 1979), 124-125.

${ }^{27}$ Max Weber, The Methodology of the Social Sciences (Illinois: Glencoe, The Free Press, 1949), 203-205. 
a segment of the life-world participants in the interaction. ${ }^{28}$ Furthermore Husserl says that "social action" should not require any interaction, ${ }^{29}$ which means that for Husserl own individual behavior or interaction (action) in the group is still considered as one whole with the term "experiencing".

Experiences (experiencing) owned by santri for studying in the cottage is a form of action that are personal without any coercion from others. Therefore, santri have to understand the causes of and attitudes that tend to be radical are not only caused by external factors such as the radicalization process by the ustad, for example, but also due to a personal experience that has been crystallized within santri interacting with the circumstances that allow the radical values to grow. In addition to that, with reference to the Abegebriel views that pesantren is allegedly the process of 'brainwashing". ${ }^{30}$ It implies that the radicalization of the learning process is based on an understanding of their interactions with the authoritarian ustad to the santri, in which the relationships and interactions are built in the education. The "educative measures" are considered dogmatic, indoctrinate, provocative and emotional. The elements and tendencies are thought to contribute to the formation of patterns of suspected radical education.

Besides the interaction of santri with an ustad, there are also the interactions and relationships between santri with environment of boarding school. Educational theory explains that milieu or environment is an aspect that is very important and urgent to be considered in shaping the output of an educational institution. Boarding school as an educational institution is responsible for providing the atmosphere or the best environment that supports the learning and achievement of learning goals. Referring to the Berns views (2010), by quoting ecological theory Uri Bronferbrenners, that humans have a reciprocal relationship with the environment. Therefore, the

${ }^{28}$ Habermas, Communication and, 125.

${ }^{29}$ Edmund Husserl, The Crisis of European Sciences and Transcendental Phenomenology (Avansto: Northwetren University Press, 1978), 120.

${ }^{30}$ A. Maftuh Abegebriel and A. Yani Abeveiro, Negara Tuhan: The Thematic Encyclopaedia (Jakarta: SR-Ins Pub., 2004), 205. 
environment gives influence to great mindset and human behavior, ${ }^{31}$ including results in psychology, social relation, and the process of cultural formation of santri all the time. Hence, the radicalization of the pesantren education can also be judged by the extent to which environmental aspects supporting their values.

Based on the Berns views, ${ }^{32}$ then boarding schools a microsystem of the larger social system is an arena or space where santri learn about the community, whether formal, informal and non-formal aspects of social lives. On the other hand, ustad encourage the development of various skills and behaviors through role models for success in learning. This means that boarding school environment as a space of interaction is taking place to form a pattern as the effects of human development. Environment cottage in this context becomes the arena of socialization and support for the values, ideologies, and culture either directly or indirectly. That is why, environment and santri are two elements that mutually influence each other. Both of these relationships form what is called by Talcott Parsons (1991) as a social system. The social system will continue to run as long as the mutual relations can be maintained. ${ }^{33}$ Therefore, ideology and any value cannot develop properly during the social system refusal, which means the value or the radical ideology allegedly flourished in pesantren is caused by the existing social system in the boarding school and receiving support those values.

\section{Exclusive Education Pattern}

Basically the system of teaching at both of boarding schools are still carried like a traditional pesantren in general, only the addition and emphasis on certain aspects. For example, differences in curriculum, learning patterns that emphasize the understanding of Islam textually and tightly, and is subservience and subject to the absolute ustad. Therefore, in the context of the education patterns, no new interpretation of space or other

${ }^{31}$ Bronfenbrenner, The Ecology, 201.

32Ibid.

33Talcott Parson, The Social System (London: Routledge, 1991), 201. 
points of view are considered true than what is taught by the ustad. Besides, the educational pattern prioritizes planting and strengthening basic values of Islam is intense like jïhad, Islamic law enforcement, and monotheism.

Exclusive education pattern, with reference to the education process, is a conscious effort to direct each santri in a belief system (system value) specified, without opening up to values beyond existing belief system. In addition, patterns can be understood in the sense of exclusiveness as an educational process based on interests and subjective assessment without considering the objective truth and false. Therefore, often boarding schools with this pattern is trying to sterilize santri's learning and understanding of the influence of external factors.

According to the sociological perspective, exclusive educational patterns automatically encourage the perish of the growth of social attitudes and can even bring anti-social behavior. The anti-social behavior referring to the notion of Berns (2010) $)^{34}$ is in in accordance with the extreme attitude shown by some radical elements who are suspected as a negative (terrorists) during this time, such as the case of the bomb and aggression that injure (expense) others. So far, the pattern of the both of boarding school with exclusive education has yet to cultivate an attitude or anti-social behavior. Although there are symptoms that lead to such attitudes, as attitudes appear suspicious of new people, the attitude of keeping others at a distance, showed reticence or not easily respond to others.

The pattern of exclusive education may appear due to the single and textual interpretation of the meaning of Qur'anic verses. The literal interpretation is only based on the viewpoint of ulama; and if it goes beyond the standpoint, it is considered wrong. The exclusive interpretation can support the claim of true attitude or deny the truth from the other, also misguided or wrongly judge the interpretation of others. In the end, this attitude can support takfiri (bigotry) attitude. Takfiri attitude is a phase where a person or groups get the theological "legitimacy" for sacrificing themselves (suicide), or in this context is associated

${ }^{34}$ Bronfenbrenner, The Ecology, 213. 
with jihad fisabilillah to combat individuals or groups who are considered enemies although the term jihad by suicide is something much different. That is, the attitude of takfiri brings the impact on aggression or extreme behavior that harms others as the peak phase of the influence of ideology. To clearly understand the description, the author illustrates the diagram below:

Figure 2 The Impact of Exclusive Education Patterns and the Phase of Attitudes Change

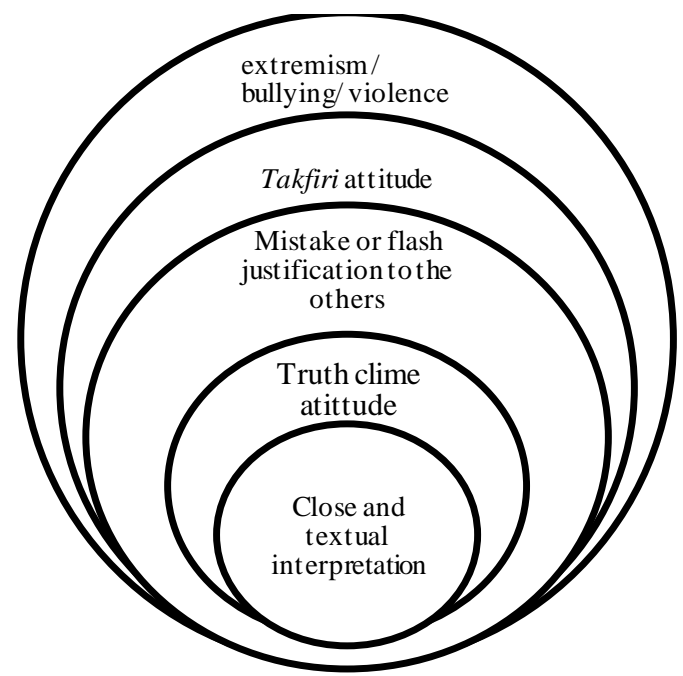

Source: The analysis results of religious attitudes change (2016)

Figure 2 illustrates some of the phases in which individuals suspected radicals and then became terrorists basically originate from individual normal conditions. In the phase of "close interpretation" and "truth claims", individuals or groups are still normal. In this phase, the individual or group tends to be the target of indoctrination with provocative, emotional, fanatic and exclusive patterns. The phase is believed by some parties as an initial phase in which new members of the group are given an understanding, perspective, and new beliefs. The process in pure terrorism is known by the term "brain washing".

After a phase of radicalism entrenches the individual or the group, they will go to a phase where people tend to use the mindset of divergent. For example, "making a choices as black 
and white". This way of thinking is shown to provide an assessment or judge others to be right or wrong according to their own point of view. The phase indicated by behavioral traits is difficult to accept differences, tends to impose the will, and the hate against those who disagree. This phase is the beginning of the individuals interact (make contact) with the surrounding environment by promoting understanding of subjective truth. Radical in the sense that upholds and fight for the values that are considered true without considering other view is also called radical thought. In this phase the scientists of Islam and the West still view the group as radical positive.

The next phase is the attitude takfiri. That attitude is a continuation of the previous phase that turns into an attitude of claiming others to be infidel. This trait in the history of the Islamic extremist group is closely related to the law of halal (permitted) or not a person to be killed as a consequence of established law. In this phase, a determination of whether the other person is worthy to fight (killed) or not is established. After this stage, the next will enter the phase where a person or group of actions or expressions such extreme physical violence, bullying, and violence. The sociological perspective of such a phase rests on the Berns view (2010) on the definition of anti-social behavior. The phase is the culmination of anti-social behavior because there are aggressive behavior and violence that harm others.

Phase takfiri is the culmination of the exclusive understanding owned by a radical group; therefore, phase takfiri is often a theological foundation in conducting jibad fi sabilillah. The terminology of takfiri in Islam has a variety of meanings, context, and purposes. For example, disbelievers in the context of kufr (economic aspect), disbelievers in the context of the denial of the command of Allah (personal-theological aspect), disbelievers in the context of monotheism that recognize other gods besides Allah (theological aspect), and believers in the context of the implementation of the law (order of values and systems of government aspect) other than Islamic law (social and political aspect). 
Referring to the results of interviews and observations in this study, the concept of takfiri understood by both of the boarding schools is generally divided in two parts. First, kafir in a theological context is concerned with understanding the concept of aqidah Islamiyah (monotheism). A person or group who believes, asks, and worships a god other than Allah is categorized as kafir. For example, people go and beg at graves or trees, can be referred to syirik that may be subject to the law of kafir. Both of the concepts of takfir are assigned to individuals or groups who do not obey the law of Allah in the affairs of the world and do not believe that the law of Allah is better than man-made laws. Therefore, individuals or groups of people who do not carry out the laws of Allah belong to the category of infidelity in narrow sense, so it can be called a kafir. For example, the law for the thief; similarly with the leadership system of the State and economy which is not based on the Islamic law can be called a kafir. Takfiri in this sense is related to social policies.

The definition of takfiri attitude in the understanding and confidence of the majority at pesantren has wide impacts. For example, a system of governance that applies in Indonesia is categorized as kafir because it is not based on the Islamic law. Consequently, all forms of legal products are considered kafir, and groups or individuals who implement and maintain the law are called taghouts. No wonder then, a leader who does not implement a good Islamic law from the highest level to the lowest level ignoring and denying the law of Allah is then called Anshorut taghouts (supporting taghouts). It is nothing to do with understanding the importance of the struggle to enforce Islamic law studied in pesantren.

Another factor that causes of exclusiveness is the rigid pattern of interpretation of Qur'an and Sunnah, literal and textual. Each textual verses and hadist understood as what is written with no space for another interpretation that allows the flexibility of meaning and dialogue between text and context. For example, in terms of of Islamic law, the Qur'an says " innalbukmi Ilallab" (no law except the law of Allah). The ustad from at UIS and MIS interpret the verse above ass the law of 
only God alone is correct. Therefore, a man-made law and lawabiding man are not important. The spirit and determination that hold, teach, and preach values are interpreted textually. Hence, it is clear that the boarding schools pertain to fundamental and radical institutes.

The pattern of exclusive religious may lead to fanaticism by promoting the narrow perspective. Hence, there appears the purification of religious elements. When referring to the view of Abegebriel (2004) on the pattern of religious understanding of radical groups that tend to be literalists-scripturalist, ${ }^{35}$ the exclusive attitude can be understood as one feature of the radicalism. The pattern of religious understanding is often stuck in a narrow ideological space, subjective norms, and closed. Subjective characteristics have led to an understanding of bound criticism and deny the other religious interpretations. While closed or exclusivist traits show the reality of the Muslims who affirm that the community is correct.

Judging from the framework of social movements, the pattern of exclusive education is aimed at creating a group identity. The identity formation is part of the collective action frame, which confirms the collective identity to explain "who we are" and "who they are". It is indirectly shown in the form of names, symbols, languages, ritual, ideology and lifestyle characteristics. Hence, the collective identity that has been internalized strongly within the santri cannot be changed by external factors.

The exclusive understanding has been ascertained implications for the pattern of social relation in society. As far as the observations made both within the schools and outside the schools, santri interaction behavior with others is not much different from the interaction of people in general. Only the interaction between the opposite sexes is very limited, both among fellow santri as well as with outsiders. It is found that free association between the sexes within these schools is strictly prohibited.

${ }^{35}$ Abegebriel and Abeveiro, Negara Tuhan, 10. 
The attitude of truth claims of the santri does not always reflect the attitude of anti-social. For santri, the tolerance is a reality that must be upheld even in certain limits. This embedded belief systems has become the choice of life or way of life for santri in the boarding schools. Therefore, it will continue to be maintained in order not to mix with ideologies that is now developing. According to the perspective of the santri and the ustad, belief systems in this case aqidah Islamiyah or monotheism are pure and clean. The spirit of upholding Islamic Shariah, and jihadfisabilillah is set in stone, as it relates to the responsibility of the individual with their God. Therefore, belief systems are not related to tolerance. Tolerance is simply related to the affairs of muamalah among people.

Learning monotheism, for example, in Islamic education, serves to transform santri into "a human who has a strong tawhic ${ }^{\prime \prime}$ in the sense of noble qualities and be committed to establishing the truth. The first pattern of expected education is the realization of santri who have a strong commitment, subject and obedience to Allah by trying to optimally run the command Allah and His messenger and being away from the ban. Second, rejecting all the guidelines and philosophy of life that does not come from Allah, like the artificial laws and the result of human thought, or better known thaghut. Third, be firm on establishing the truth, between the haq and babtil. For example, if social behavior is syirik or contravenes the Qur'an and Hadiths, it is subject to change, so it can be returned in accordance with the provisions of Allah. Fourth, the purpose of life is very clear that all solely for Allah in a manner that has been exemplified by the Prophet.

For Islamic boarding schools, the value system (ideology) is something essential. Consequently, each santri must accept the values during their scholarly journey in the schools. Ideology (belief system) is something final, which means no more rooms for discussion or changes in it. Ideology is something that is stored neatly and firmly in the minds and hearts of those who believe in it, because it tends to not be seen by the eye. Ideology then affects and determines how a person or group should behave and look at something. This case is regarded as mental models in 
this study. The mental processes in many ways influence and determine the characteristics and mindset (way of thinking), which means that the thoughts that have been patterned have its own structure.

It cannot be clearly observed between mental models and way of thinking although it is believed to be a change of mental models to be mindset. Furthermore, the observed diversity pattern is summarized in the events that are a reflection of a behavior that can be observed and evaluated. The above description can be explained by the diagram below.

Figure 3 Orientation Changes in Education Pesantren

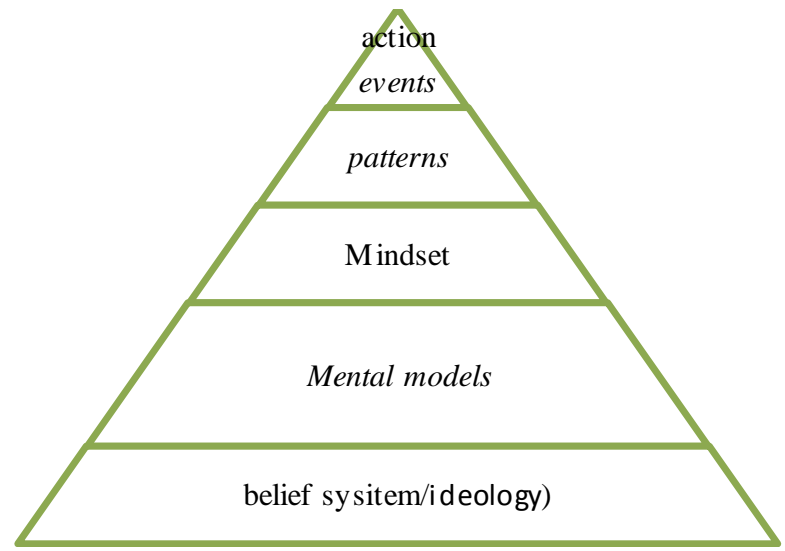

Source: The results of the data analysis of changes

in the orientation of education pesanteren (2016)

Based on the Figure 3, the event is an event or observable something. For example, in the context of Islamic boarding schools, santri behave nicely towards fellow santri (such as mutual help and solidarity), behavior towards others (such as anti-social behavior or pro-social), as well as personal attitudes (such as learning behaviors and everyday life). All events or observed symptoms associated with these schools are a phenomenon that is important and meaningful. Behavior of santri and an ustad which appears in the context of this study can be interpreted as anything related to invisible matters, such as the believed value system or ideology.

On the other hand, patterns are activities, thoughts and behaviors that occur repeatedly in a boarding school 
environment. Behavior of santri or event observed derives from something that has been patterned consciously and unconsciously. Therefore, in a phenomenological study, the occurrence of a particular event linked to other events. All events in the phenomenological perspective has its own chronologies and follow the cause and effect that can be interpreted. Between the events and the pattern is something that reveals itself; hence, these can be assessed and reviewed. The immerging events and patterns are dependent upon the primordial mindset. Way of thinking in the context of this study is an aspect that is not visible but influences and even determines the patterns and events that are about to happen. Indoctrination process that occurs in a boarding school education, for example, is more directed to form a novel mindset of the santri, like building divergent thinking, black or white, lawful or unlawful, and unbelievers or faith.

Ways of thinking are shaped or influenced by the mental models (perspectives, attitudes toward many things). Mental model is the assumption held by individuals and organizations to determine how an organization thinks and acts, so mental models can also be a barrier for organizational learning. In this study, the way santri and ustad think is determined by the mental models. The previously buildt mental models make individuals find in difficult to accept different point of views and remain fanatic, exclusive and self-claimed true. That is why, the santri show behavior that is difficult to change and influence. On the other hand, mental models come from the container (the unquestioned belief); for example, ideology or belief system that already exists. Container is something that is dogmatic, and therefore tends to be accepted and is taken for granted by every santri or ustad.

\section{Indoctrination}

The process of indoctrination is based on a system of values that instills ideas, attitudes, systems thinking, behavior, and belief. This practice differs from the notion of education because it does not involve the process of critical thinking, questioning whether the transferred knowledge is true or not. In 
fact, the general conduct of educational tradition in Islamic boarding school often takes indoctrination form. Despite this being the culture in such schooling context, ustad is a man who must be respected, heard and honored. The difference lies in that the culture is closely related to the tradition of learning in the schools that puts the two schools stress on the importance of strong bond among the school members, which is often referred as the allegiance (oath/bai'at), in which it demands loyalty and sacrifice. The condition has reinforced the notion that the two boarding schools are indoctrinating their values to the santri as part of the learning process.

The notion that education boarding schools have made the process of internalizing the ideology of "force" to santri is not the first time because since the outbreak of terrorism cases that have an impact on schools linkages with radicalism, many pesantren have been accused for the process of "brainwashing" the santri through the patterns of its teaching. As stated by Abegebriel that at least there are three models of how radicalism appear in boarding schools. First, they are recruited by activist in boarding schools to join the doctrine applied by the pesantren Second, pesantren alumni are recruited to preaching and jibad. Third, they have specific skills in making bombs ${ }^{36}$. Referring to these models, it is assumed that the alleged stigmatization of both schools toward terrorism has been a form of political stereotype of certain parties that need to be investigated further. However, it is understood that both the pesantren education emphasizes the enforcement of Islamic law, the purity of monotheism, and da'wah wal Jihad, an excuse for some people to associate these schools with the issue of radicalism and terrorism.

\section{Conclusion}

Grounded in the negative connotation of radicalism characterized by the provision of the exclusiveness and indoctrination and the curriculum enforcing the implementation of Islamic law and jibad fisabilillah in the pattern of pesantren

36Ibid., 230-233. 
education, the two schools disseminate radicalism. This hypothesis is based on the assumption that radicalism has negative and positive meanings. Radicalism can also be divided into two forms, namely in the form of the theory of radical (radical understanding) and practical radical (radical behavior). It is also associated with the pattern of secondary education schools, which tend to be radical as indicated by hegemonic, authoritarian, and exclusive instructional practices. In addition, it is also found that there are several objectives of indoctrination process. First, indoctrinate orients the ideology to be internalized in the teachers (ustad). Second, indoctrination aims for attitude (truth claims). Third, indoctrination influences the characteristic formation of the santri. Fourth, indoctrination orients value reinforcement.

The open management system may deny the radical stigmatization against any Islamic boarding schools; however, Islamic boarding schools were built to accommodate the needs of people who cannot afford education. Therefore, such a negative stigmatization attached to the two Islamic boarding schools, according to the leader, is simply a political propaganda. On the other hand, the schools recognize that there are many factors promoting such a radical stigma, including the absence of the national curriculum and the alleged affiliation of the school superintendents with the terrorist groups beyond the schooling wall.

\section{References}

Abegebriel, A. Maftuh, and A. Yani Abeveiro. Negara Tuban: The Thematic Encyclopaedia. Jakarta: SR-Ins Pub., 2004. Al-Attas, Syed M. Naquib. Filsafat dan Praktek Pendidikan Islam. Jakarta: Mizan, 2003.

Ali, Tariq. Benturan Antar Fundamentalis, Jihad Melawan Imperialisme Amerika. Jakarta: Paramadina, 2004.

al-Athari, 'Abdullāh bi 'Abd al-Hāmid. Aqidah Salaf; Ablul Sunnah wal Jama'ah. Jakarta: Pustaka al-Inabah, 2015.

Bronfenbrenner, Urie. The Bioecological Model of Human Development. New York: National Academy Press, 2006. 
. The Ecology of Human Development: Experiments by Nature and Design. Cambridge, Massachusetts, and London, England: Harvard University Press, 1979.

Dhofier, Zamakhsyari. Tradisi Pesantren, Studi tentang Pandangan Hidup Kyai. Jakarta: LP3ES, 2015.

Esposito, John L. Ancaman Islam Mitos atau Realitas, Edisi Revisi: Menggugat Tesis Huntington. Bandung: Mizan, 1996.

Habermas, Jurgen. Communication and the Evolution of Society. Boston: Beacon Press, 1979.

Hodgson, Marshall G.S. The Venture of Islam, Iman dan Sejarah dalam Peradaban Dunia. Translated by Mulyadhi Kartanegara. Jakarta: Paramadina, 2002.

Husserl, Edmund. The Crisis of European Sciences and Transcendental Phenomenology. Avansto: Northwetren University Press, 1978.

Mbai, Ansyaad. Dinamika Baru Jejaring Teror di Indonesia. Jakarta: AS Production, 2014.

Miller, Reuben. "The Literature of Terrorism." Terrorism 11, no. 1 (January 1988): 63-87.

Nuh, Nuhrison M. Peranan Pesantren dalam Mengembangkan Budaya Damai. Jakarta: Puslitbang Kemenag, 2010.

Parson, Talcott. The Social System. London: Routledge, 1991.

Rahardjo, M. Dawam, and et. al. Pesantren dan Pembaharuan. Jakarta: LP3ES, 1995.

Roy, Oliver. Geneologi Islam Radikal. Edited by Ali Noer Zaman. Translated by Narullah Ompu Bana. Yogyakarta: Genta Press, 2005.

Weber, Max. The Methodology of the Social Sciences. Illinois: Glencoe, The Free Press, 1949.

Wikipedia. Accessed September 9, 2016. https://id.wikipedia.org/wiki/Pola.

Wilner, Alex, and Claire-Jehanne Dubouloz. "Homegrown Terrorism and Transformative Learning: An Interdisciplinary Approach to Understanding Radicalization." Global Change, Peace \& Security 22, no. 1 (March 10, 2010): 33-51. 